\title{
Article
}

\section{Student Leadership at the University: An Explanatory Model}

\author{
María Pilar Cáceres-Reche ${ }^{1}{ }^{\circledR}$, Miguel López-Gómez ${ }^{2}$, Fernando José Sadio-Ramos ${ }^{3}{ }^{\circledR}$, Blanca Berral-Ortiz ${ }^{1}$ and \\ José Antonio Martínez-Domingo ${ }^{1, *(1 D}$ \\ 1 Department of Didactic and School Organization, University of Granada, 18011 Granada, Spain; \\ caceres@ugr.es (M.P.C.-R.); blancaberral@correo.ugr.es (B.B.-O.) \\ 2 Department of Humanities, University of Santo Tomás, Bucaramanga 680002, Colombia; \\ milogo01@ustabuca.edu.co \\ 3 Scientific Area of Psychology and Educational Sciences, Polytechnic of Coimbra, 3045-093 Coimbra, Portugal; \\ framos@esec.pt \\ * Correspondence: josemontejicar@correo.ugr.es
}

check for updates

Citation: Cáceres-Reche, M.P.; López-Gómez, M.; Sadio-Ramos, F.J;; Berral-Ortiz, B.; Martínez-Domingo, J.A. Student Leadership at the University: An Explanatory Model. Educ. Sci. 2021, 11, 703. https:// doi.org/10.3390/educsci11110703

Academic Editor: James Albright

Received: 22 September 2021

Accepted: 26 October 2021

Published: 2 November 2021

Publisher's Note: MDPI stays neutral with regard to jurisdictional claims in published maps and institutional affiliations.

Copyright: (c) 2021 by the authors. Licensee MDPI, Basel, Switzerland. This article is an open access article distributed under the terms and conditions of the Creative Commons Attribution (CC BY) license (https:// creativecommons.org/licenses/by/ $4.0 /)$.

\begin{abstract}
The exercise of leadership in the educational area and its diverse forms of being reflected in practice continue to arouse interest at the time of designing and developing research that reveals the characteristics that a leader must have in order to be considered a competent university leader, that is, a college student who carries out activities and a leadership position on his or her campus. In this sense, the present work aims to analyze the profile of the student leader to generate an explanatory model, being answered by means of a series of questions. Next, a cross-sectional study of university students at the University of Santo Tomás is carried out, obtaining statistical-descriptive data that indicate the mean scores in relation to each of the dimensions of the sociodemographic factors of this research. In addition, gender and age are identified as study factors that coincide with other research, as well as the qualities, expectations and formation of the student leader. In the present study, female gender is significant in relation to leadership practice, and age does not show significant differences between the groups. Finally, it is concluded by determining as key the role of students who exercise leadership in the University. In addition, it should be noted that the present research is derived from the Doctoral Thesis entitled: "Student leadership at the University Santo Tomás de Bucaramanga: Pedagogical proposal", defended at the University of Granada, Spain. Funded by Proyecto de investigación, Colombia. Code: 2008/12058.
\end{abstract}

Keywords: leadership; student leadership; educational leadership; higher education

\section{Introduction}

Leadership is one of the great challenges that societies and institutions must solve in order to achieve goals and objectives and, thus, sustainable and integral human development. In today's society, the challenges that arise are increasingly changing, including the need to create new consensuses, to develop egalitarian visions of individuals, to reduce social inequalities and to alleviate poverty rates: in short, to emphasize the role of social justice and human rights.

All this entails designing and planning a series of real and practical strategies that take into account alternative models of action and problem solving. Among the challenges to be taken on, we find a reorientation of political and social actions that have the common good as their ultimate goal.

The scope of this common good must be fostered in young people, making them participants in the construction of democracy through social participation, freedoms, duties, rights and empowerment. In addition, leadership among young people should be oriented to the service of the public with training in ethical values, policies, social commitment and training to promote real transformations that the country and its citizens require.

Thus, the university must seek and achieve in one way or another the formation of young students with humanistic, ethical, critical and servant leadership profiles so that they 
can contribute to the political and cultural transformation of communities [1]. Likewise, from the United Nations [2], a call was made to all sectors of society to mobilize based on three levels: actions at global levels to ensure greater leadership, actions at local levels and actions by individuals, in this sense including youth and, with it, student leadership.

\section{Conceptualization of the Term Leadership}

Researchers such as El Homrani et al. [3] establish that leadership is not a position but a process. In this sense, the positions on the definition of the term leadership maintain different perspectives, which is why they are diverse. Some authors establish and focus on personality issues, behaviors and even on the physical traits of the leader himself; on the other hand, others have analyzed how the contexts and characteristics in which the leader develops influence and affect the way of proceeding of the so-called leaders [4]. There are also those who choose to take a more radical view, arguing that leadership itself does not exist but rather that it is organizational failures and successes that are attributed to the so-called leaders. In line with the above, the consequences of how an institution functions goes beyond any role that an individual or a group may play and beyond the subject itself. Another perspective from which leadership has been approached throughout history has been based on social justice and inclusion [5].

It can be said that this work certainly emphasizes leadership style from a more individual approach in order to highlight its importance and personal imprint in this specific context. Although it is true that the scientific literature and also our broader vision of this research is framed in speaking more of leadership than of leaders, trying to converge both the vision that "the leader is born and made" and that it is the situation that creates the leaders. It is, therefore, a dynamic function that resides in the group and is oriented towards a common objective and a shared project [6].

Taking into account these definitions, it can be said that leadership is a process by which an individual or a group of individuals exert a systematic majority influence on others when developing certain functions that compete with them to achieve shared objectives, at the same time becoming a reference and figure to follow for other people [1]. Thus, leadership can be understood as a process by which a subject incites a subordinate to behave and/or act in a certain desired way, coordinating and directing the work of the group members and where such interpersonal relationships are not carried out by obligation but by the desire of the individuals themselves $[7,8]$.

Leadership also implies a process of transformation by creating diverse visions of the results to be achieved, as well as an articulation of the objectives so that they can be achieved. Leadership should be seen as a process by which the influence that the leader exerts is necessary to direct and subordinate a group and organize towards the achievement of the established goals and success, all this through different actions focused on the construction of opportunities and conditions for the work team to be effective and efficient.

From the various metaphors collected and in the specific literature by Lorenzo [6], it can be understood as intuitive, cross-cultural, strategic, visionary, global, ethical, resultsbased, instructive and creative leadership, among others. Within all metaphors, we place ourselves in the political leadership that university students exercise through their representatives. As a group, they have the power to have a say in aspects related, for example, to syllabi, specific content or problems that may arise with specific professors. Likewise, they have a say in the election of the dean, rector or director of a department.

According to relevant authors on the subject such as Lorenzo et al. [9] and Hermosilla et al. [10], student leadership in university institutions is an institutional leadership carried out through a threefold technical, transformational and interpretative process. Therefore, universities as institutions and contexts of social interaction, become the ideal place to give voice and have the students' opinion present in the components of the governing bodies.

Undoubtedly, the election and participation of leaders is a complex issue that entails great responsibilities, since such election will contribute positively or negatively in the 
work that the fortunate representatives will perform. Therefore, a great screening must be carried out based on certain criteria of competencies and qualities, among others, that a suitable leader must have. In addition, the extent to which sociodemographic factors influence the profile of a student leader should be analyzed [11].

The leader is an agent who seeks to transform the environment in a positive way, making available to society or the group that conforms their skills, values and knowledge to develop initiatives that produce social impact and generate positive changes in groups and/or communities, promulgating the values of the institution [12].

In terms of student leadership, we find several ways of expressing them [13]:

- Social leader: students who present interests in social change and lead initiatives or self-managed and autonomous volunteer organizations;

- $\quad$ Representative leader: students who hold representative positions, democratically elected by their peers and who develop university policy initiatives that serve the university community;

- Healthy life leader: students who understand a formation in health areas, so they implement and develop campaigns and activities that promote healthy life habits;

- $\quad$ Sports leader: leaders who, along with fulfilling academic responsibilities, master extraordinary skills for sports, channeling it in the university teams and representing the university.

The main characteristics that a good student leader should have are the following [14]:

- Honesty: He/she must be a student of integrity and honesty, in addition, he/she must show rectitude. This characteristic is essential for that person who aspires to be a voice and leader of others, because he/she must earn the trust of a group.

- Empathy: It is really necessary to know how to put oneself in the other person's place because it allows us to better understand others, helping to reach out to them so that they can achieve their goals. Likewise, managing personal relationships is one of the most relevant characteristics of leadership.

- Communication skills: A good communicator and a good leader must listen. At the same time, he/she must have the ability to attend to and understand the needs of others and must treat everyone equally; in this sense, there cannot be some above others.

- Interaction: It is transcendental that the leader works as a team with other leaders or referents of the subject in question. This is as much about sharing methods and knowledge as it is about learning and listening from those who know the most; it is a quality that denotes commitment, interest and tolerance towards different points of view. This directly enriches the area in which the leader works, becoming of benefit to the entire university student community.

- Commitment and initiative: A competent leader takes the initiative to be aware of everything that happens in the area in which they are involved, identify the needs of the group and propose possible solutions.

However, after all of the above, it is necessary to emphasize that for good leadership there must be a constant dialogue in which each and every opinion counts equally.

Consequently, the objective of this study was to analyze the student leader's profile in order to generate an explanatory model. The research questions posed were:

RQ1. Are there significant differences in the student leader profile as a function of sociodemographic factors?

RQ2. Do sociodemographic factors influence the student leader profile?

RQ3. How do leadership qualities, expectations, training and practice influence the student leader profile? 


\section{Methodology}

\subsection{Research Design and Participants}

A cross-sectional study design was adopted using a self-administered survey in the population of university students of the Universidad Santo Tomas (USTA), Bucaramanga section (Colombia). Therefore, the research was carried out based on non-probability purposive sampling. The sample was finally made up of 152 student representatives. Thus, all respondents were informed about the purpose of the study and the anonymous treatment of their data. Student representatives in different governing bodies of the University were invited to participate by sending an invitation by email from the Student Delegation and also through the tutor lecturers of each group, as well as by contacting the coordinators of the degree programs, so that they could pass on all the information.

Specifically, the sample was defined by 28 males and 124 females, aged 15-26 years $(\mathrm{M}=21.04 ; \mathrm{SD}=3.72)$. Table 1 shows the sociodemographic data of the participants.

Table 1. Sociodemographic data.

\begin{tabular}{ccc}
\hline & $n$ & $\%$ \\
\hline $\begin{array}{c}\text { Gender } \\
\text { Male }\end{array}$ & 28 & 18.4 \\
Female & 124 & 81.6 \\
Age & & \\
$15-18$ & 84 & 55.3 \\
19-26 & 68 & 44.7 \\
Position & 108 & 71.1 \\
Course Representative & 28 & 18.4 \\
Faculty Council & & \\
Representative & 4 & 2.6 \\
General Representative of the & & 7.9 \\
Academic Council & 12 & \\
Special Representative of the & & 73.7 \\
Academic Council & 112 & 23.7 \\
Time & 36 & 2.6 \\
1-2 years & 4 &
\end{tabular}

Note: $n=$ number of people for each factor; $\%=$ percentage of each factor.

\subsection{Measure}

The Student Leadership Scale (ELE) was used to assess the profile of the student leader [11]. The scale measured qualities (25 items), expectations (22 items), training (11 items) and leadership practice (11 items) through a total of 69 items, with a four-point Likert response mode ( $1=$ strongly disagree; $4=$ strongly agree). The scores ranged for each dimension between 25 and 100 points for qualities, 22 and 88 for expectations, 11 and 44 for training and 11 and 44 for leadership practice. Higher values on the scale indicated a higher degree in each dimension. The scale has adequate psychometric properties; the reliability obtained in this study through Cronbach's Alpha coefficient was adequate $(\alpha=0.814)$.

\subsection{Data Analysis}

Statistical-descriptive values were established for the mean and standard deviation of each sociodemographic factor with respect to the dimensions of the scale. In turn, the possible existence of significant differences between the sociodemographic factors was analyzed with the $\mathrm{T}$ test for independent samples when they were dichotomous (gender, age) and the ANOVA test when more than two groups were established (position, time). Finally, a structural equation model (SEM) was constructed from the path analysis, where the relationships between endogenous and exogenous variables were established. The 
different analyses were carried out with the IBM SPSS and IBM SPSS Amos, version 25 (IBM Corp., Armonk, NY, USA) statistical packages.

\section{Results}

The statistical-descriptive data show the mean scores for each dimension, obtained for each of the sociodemographic factors of the study. At the same time, any significant differences were recorded (Table 2). In gender, the highest mean score was found in the female group in all dimensions, and significant differences were only found with respect to leadership practice $(p=0.03)$. Regarding age, no significant differences were found between the two groups, and the scores were similar in each dimension. The position of the student representative was significant in qualities $(p=0.02)$ and training $(p=0.00)$, and the highest mean was obtained by the General Representative of the Academic Council, except in training, which was obtained by the Special Representative of the Academic Council. Finally, no significant values were obtained for seniority in terms of the length of time the student has been in the position. In qualities, training and practice, those with more than four years had the highest mean, while those with 1-2 years obtained the highest mean in expectations.

Table 2. Descriptive statistical data and differences between groups.

\begin{tabular}{|c|c|c|c|c|c|c|c|c|c|c|c|c|}
\hline \multirow{2}{*}{ Factors } & \multicolumn{3}{|c|}{ Qualities } & \multicolumn{3}{|c|}{ Expectations } & \multicolumn{3}{|c|}{ Training } & \multicolumn{3}{|c|}{ Practice } \\
\hline & $\mathbf{M}$ & SD & $p$ & $\mathbf{M}$ & SD & $p$ & $\mathbf{M}$ & SD & $p$ & $\mathbf{M}$ & SD & $p$ \\
\hline \multicolumn{13}{|l|}{ Gender } \\
\hline Male & 73.3 & 5.5 & \multirow{3}{*}{0.21} & 67.9 & 5.9 & \multirow{3}{*}{0.13} & 33 & 3.7 & \multirow{3}{*}{0.10} & 30.1 & 5 & \multirow{3}{*}{0.03} \\
\hline Female & 75 & 6.7 & & 69.1 & 3.1 & & 34.2 & 3.4 & & 32.1 & 4.2 & \\
\hline Age & & & & & & & & & & & & \\
\hline $15-18$ & 75.3 & 6.2 & \multirow{3}{*}{0.20} & 68.9 & 4 & \multirow{3}{*}{0.90} & 34.2 & 3.4 & \multirow{3}{*}{0.30} & 31.3 & 4.8 & \multirow[b]{2}{*}{0.21} \\
\hline 19-26 & 73.9 & 6.9 & & 68.9 & 3.5 & & 33.7 & 3.6 & & 32.2 & 4 & \\
\hline \multicolumn{10}{|l|}{ Position } & & & \\
\hline CR & 75.4 & 6 & \multirow{5}{*}{0.02} & 68.6 & 4 & \multirow{4}{*}{0.14} & 34.1 & 3.4 & & 31.9 & 4.4 & \\
\hline FCR & 74 & 5.8 & & 69.1 & 3.8 & & 34.7 & 3.4 & \multirow{3}{*}{0.00} & 31.3 & 5.1 & \multirow{4}{*}{0.10} \\
\hline GRAC & 78 & 0.3 & & 73 & 0.3 & & 37 & 0.2 & & 27 & 0.4 & \\
\hline SRAC & 68.3 & 9.4 & & 68.3 & 0.49 & & 29.7 & 3.5 & & 33 & 0.85 & \\
\hline Time & & & & & & & & & & & & \\
\hline $1-2$ years & 75 & 6.1 & \multirow{3}{*}{0.30} & 69.25 & 4 & \multirow{3}{*}{0.06} & 33.8 & 3.3 & \multirow{3}{*}{0.06} & 32.1 & 4.9 & \multirow{3}{*}{0.08} \\
\hline $3-4$ years & 73.3 & 7.9 & & 67.9 & 3.1 & & 34.1 & 4 & & 30.3 & 2.3 & \\
\hline$>4$ years & 77 & 0.4 & & 66 & 0.2 & & 38 & 0.3 & & 33 & 0.2 & \\
\hline
\end{tabular}

Note: $\mathrm{CR}=$ Course Representative; FCR = Faculty Council Representative; GRAC = General Representative of the Academic Council; SRAC $=$ Special Representative of the Academic Council.

For the preparation of the SEM, it was essential to verify the hypothesis of multivariate normality of the data. Multivariate normality was confirmed by means of Mardia's coefficient, where a value of 15.78 was obtained, which was lower than $p^{*}(p+2)$, where $p$ corresponds to 69 (number of observed variables) [15]. The existence of multivariate normality confirmed the adequacy of the data for the construction of the SEM. The goodness-of-fit indices of the model were adequate, following Byrne [16] (Table 3).

With regard to the path analysis, the dimensions that make up the student leader profile were broken down. Thus, connections were established between the sociodemographic factors and the dimensions of the scale. Relationships were established between gender, age, position and time with qualities and expectations. At the same time qualities and expectations were associated with training and practice (Table 4). Significant values were established between age and qualities $(p=0.013)$; position and qualities $(p \leq 0.001)$; gender and expectations $(p=0.049)$; time and expectations $(p=0.003)$; qualities and training $(p \leq 0.001)$; and training and practice $(p=0.002)$. 
Table 3. Goodness of fit measure.

\begin{tabular}{ccc}
\hline Fit Indices & Obtained Values & Criteria \\
\hline$\chi^{2}$ & 32.84 & \\
$d f$ & 13 & $\leq 3$ \\
$\chi^{2} / d f$ & 2.52 & $\geq 0.90$ \\
GFI & 0.953 & $<0.05$ \\
RMSEA & 0.045 & $\geq 0.90$ \\
NFI & 0.934 & $\geq 0.90$ \\
CFI & 0.933 & $\geq 0.90$ \\
AGFI & 0.971 & $<0.08$
\end{tabular}

Note: GFI = Goodness-of-Fit Index; RMSEA = Root Mean Squared Error of Approximation; NFI = Normalised Fit Index; CFI = Comparative Fit Index; AGFI = Adjusted Goodness-of-Fit Index; SRMR = Standardized Root Mean Square Residual.

Table 4. Parameter estimates of final model.

\begin{tabular}{cccccc}
\hline Associations between Variables & RW & SE & CR & $p$ & SRW \\
\hline Gender $\rightarrow$ Qualities & -0.743 & 1.292 & -0.575 & 0.566 & -0.047 \\
Age $\rightarrow$ Qualities & -1.621 & 1.060 & -2.474 & 0.013 & -0.200 \\
Position $\rightarrow$ Qualities & -2.271 & 0.598 & -3.796 & $* * *$ & -0.307 \\
Time $\rightarrow$ Qualities & -0.609 & 1.039 & -0.586 & 0.558 & -0.048 \\
Gender $\rightarrow$ Expectations & 1.520 & 0.771 & 1.972 & 0.049 & 0.163 \\
Age $\rightarrow$ Expectations & 0.271 & 0.632 & 0.428 & 0.669 & 0.035 \\
Position $\rightarrow$ Expectations & 0.109 & 0.357 & 0.307 & 0.759 & 0.025 \\
Time $\rightarrow$ Expectations & -1.832 & 0.620 & -2.957 & 0.003 & -0.245 \\
Qualities $\rightarrow$ Training & 0.364 & 0.031 & 11.551 & $* * *$ & 0.683 \\
Qualities $\rightarrow$ Practice & 0.076 & 0.073 & 1.054 & 0.292 & 0.113 \\
Expectations $\rightarrow$ Training & -0.057 & 0.054 & -1.059 & 0.290 & -0.063 \\
Expectations $\rightarrow$ Practice & -0.068 & 0.091 & -0.751 & 0.453 & -0.059 \\
Training $\rightarrow$ Practice & -0.420 & 0.137 & -3.074 & 0.002 & -0.331 \\
\hline
\end{tabular}

Note: RW = regression weights; $\mathrm{SE}$ = standard error; $\mathrm{CR}$ = critical radio; SRW = standardized regression weights $* * * p<0.001$.

The graphical expression of the path analysis showed the relationship of factors, where the main constructs were as follows: qualities, expectations, training and practice (Figure 1). The percentage of variation of each construct established by the coefficient of determination was $10 \%$ for qualities $\left(R^{2}=0.103\right), 6.3 \%$ for expectations $\left(R^{2}=0.063\right), 47 \%$ for training $\left(\mathrm{R}^{2}=0.471\right)$ and $7.2 \%$ for practice $\left(\mathrm{R}^{2}=0.072\right)$.

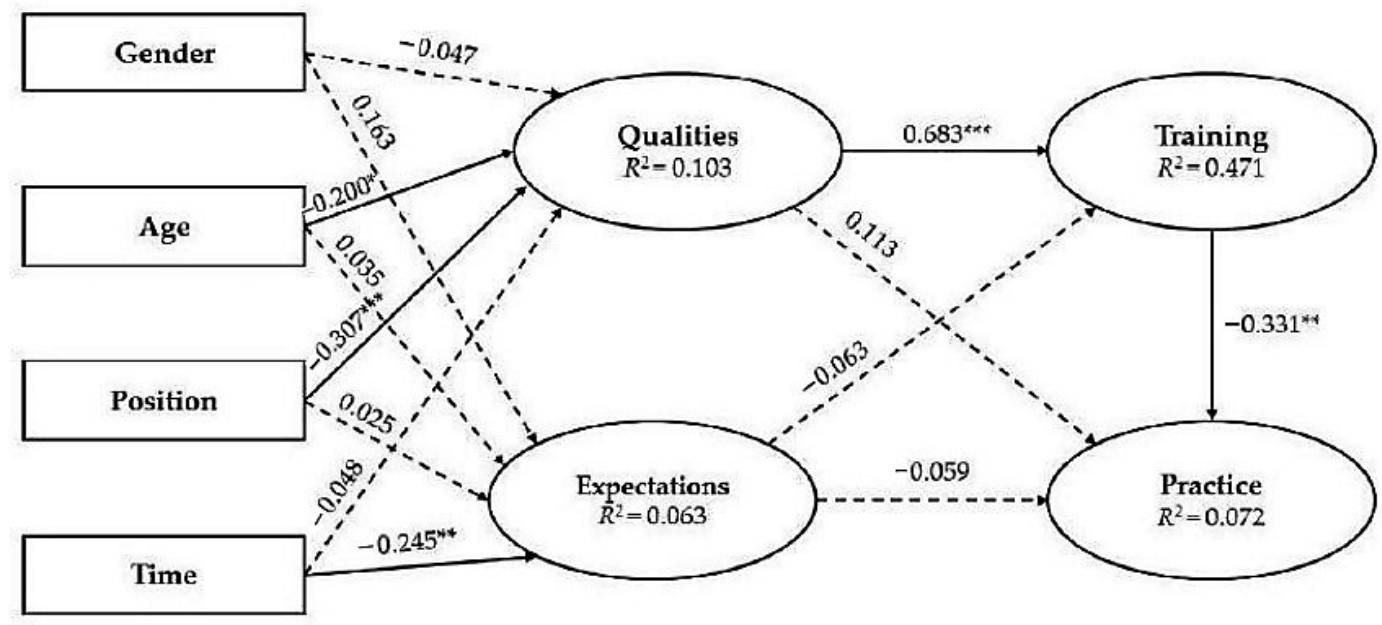

Figure 1. Path analysis. Note: ${ }^{*}$ Significant at $p<0.05 ;{ }^{* *}$ Significant at $p<0.01 ;{ }^{* * *}$ Significant at $p<0.001$. Discontinuous arrow $=$ not significant. 


\section{Discussion}

The highest mean score was found in the female group in all dimensions, with significant differences found in leadership practice $(p=0.03)$. Leadership practice refers to "what they do on a daily basis", their tasks and functions as representatives of their classmates (class group delegates, in Governing Boards, etc.), highlighting the techniques used, how they work, difficulties and possibilities detected. Thus, there is agreement with other studies in which women show greater leadership [17]. However, other research indicates that although women are achieving greater leadership, this does not occur equally [18]. Better leadership can be understood as an energizing leadership style, capable of dynamizing and adapting to the context, fulfilling the proposed objective, that is to say, to perform an effective and successful representation of peers.

In addition, the gender factor in relation to leadership has been investigated in numerous previous studies, focusing on stereotypes, gender bias, the relegation of women and the minority of women in management positions [19,20]. Even so, it should be noted [21], within the representation of students, that gender is not a factor that is understood to be decisive when it comes to performing certain functions that they have to carry out, and the assertion that gender has an influence on leadership is not accepted.

In age, no significant differences were found between the two groups, and the scores were similar in each dimension. Age was also taken into account in different research identifying the age of the sample, creating groups of people by age range [18], as well as determining that university leaders do not have a specific age, as it varies between 18 and 43 years, with the main focus of leaders being between 21 and 24 years of age (47.8\%) [22].

The position of the student representative was significant in qualities $(p=0.02)$ and training $(p=0.00)$, and the highest mean was obtained by the General Representative of the Academic Council, except in training, which was obtained by the Special Representative of the Academic Council. Thus, qualities and student representation are aspects to be taken into account in a leader [3].

The length of time the student has held the position did not have significant values. In qualities, training and practice, those with more than 4 years had the highest mean, while those with 1-2 years had the highest mean in expectations. It is interesting to note that the longer the student has been in the position, the lower the expectations.

Age and position were factors influencing student leader qualities, while time in office influenced expectations. In addition, the qualities of the student leader influenced education. In turn, training influenced leadership practice. In addition, other aspects that a leader should have according to several authors [3] focus on know-how and personal values regardless of the branch of knowledge.

In addition, a student leader must know about emotional education, understood as increasing the professional training of students, with the intention that they develop, strengthen and acquire good student leadership so that students can successfully face all the challenges of the 21st century linked to a successful education [23].

\section{Conclusions}

Taking into account the results obtained, it can be concluded that the research questions posed have been answered. On the one hand, the profile of the student leader has been determined depending on the sociodemographic factors, identifying those that influence the profile of the student leader. Furthermore, in the results section, the way in which leadership qualities, expectations, training and practice influence the profile of the student leader has been developed, finding that women score significantly higher in leadership practice, that is to say, they perform an effective and successful representation of peers in the tasks they perform and in the representation of their peers.

In turn, it can be said that the majority of student leaders at the University tend to be young, usually between 18 and 23 years of age, with a minority of students being older [22].

In addition, student leaders are selected with the intention of acting as communicators between students and the institution, being good mediators when conflicts arise and 
advocating for students in the face of difficulties [3]. Thus, it has been identified that student leaders stand out for their qualities and training, so they must be competent to take on the role of leader. Age and position also influence the qualities, as well as gender and time in the expectations that are presented, among other significant relationships, being links to consider when identifying a good student leader.

When students are trained in leadership and participate in student organization, it can lead to the University and the school developing a society of professionals who exercise their rights as citizens, with the intention of increasing the chances of good social development. For this reason, carrying out different projects in which ethics and politics are taught through different practices that lead to an integral formation of the student body [24].

Thus, there is a variety of literature that points to the importance of students acquiring leadership behaviors and skills when carrying out work. When reviewing the way in which leadership affects the organization of work, it is identified that it is necessary to develop leadership on the part of the members who carry out this work, having benefits when it comes to professional organization [25].

On the other hand, it can be said that one of the limitations of this study is that although leadership is predominantly by women, both in students, as is the case in this study, and in teachers [17]. Due to the fact that the sample of this study has a greater number of female presences, this could influence the higher scores in women, therefore it could be improved with a group with a similar number of men and women.

For the above reason, as a prospective study, student leadership should continue to be studied with a sample that allows us to determine whether gender really has an impact on the development of student leadership at the university. In order to do this, the sample should be representative and with a similar number of men and women.

In short, student leadership is an issue of great relevance, due to the fact that students achieve training and also a background during the stage in which they are being trained, such as at a university, being a previous step in learning about leadership before they become professionals [21].

Author Contributions: Conceptualization, M.P.C.-R. and M.L.-G.; Data curation, M.L.-G.; Formal analysis, M.L.-G.; Investigation, M.L.-G., B.B.-O. and J.A.M.-D.; Methodology, M.P.C.-R., M.L.-G., B.B.-O. and J.A.M.-D.; Project administration, M.L.-G.; Supervision, M.P.C.-R.; Validation, M.L.-G.; Visualization, M.L.-G., B.B.-O. and J.A.M.-D.; Writing-original draft, B.B.-O. and J.A.M.-D.; Writingreview \& editing, M.P.C.-R., F.J.S.-R., B.B.-O. and J.A.M.-D.; All authors have read and agreed to the published version of the manuscript.

Funding: Study funded by Proyecto de investigación Colombia. Code: 2008/12058.

Conflicts of Interest: The authors declare no conflict of interest.

\section{References}

1. López, M.; Cáceres, M.P.; Agreda, M. Estudio sobre liderazgo estudiantil desde un enfoque socio-político en la Universidad Santo Tomás de Bucaramanga (Colombia). IJELM 2017, 5, 178-197. [CrossRef]

2. United Nations. The 2030 Agenda and the Sustainable Development Goals, Santiago. 2018. Available online: https://www.un. org/sustainabledevelopment/es/development-agenda/ (accessed on 24 October 2021).

3. El Homrani, M.; Conde, A.; Ávalos, I. Student leadership and branches of knowledge: An approximate study at the University of Granada. IJELM 2016, 4, 177-197. [CrossRef]

4. Barnett, K.; McCormick, J. Leadership and team dynamics in senior executive leadership teams. Educ. Manag. Adm. Leadersh. 2012, 40, 653-671. [CrossRef]

5. Valdés, R.; Gómez Hurtado, I. Competencias y prácticas de liderazgo escolar para la inclusión y la justicia social. Perspect. Educ. 2019, 58, 47-68. [CrossRef]

6. Lorenzo, M. El liderazgo en las organizaciones educativas: Revisión y perspectivas actuales. Rev. Esp. Pedagog. 2005, 232, 367-388.

7. Lorenzo, M.; Cáceres, M.P.; Aznar, I.; Hinojo, F.J.; Trujillo, J.M. Aportaciones actuales del liderazgo estudiantil en el contexto italiano: La Universidad de Bolonia. Educ. Siglo XXI 2011, 29, 313-332.

8. Varón, E.K. Liderazgo Educativo Siglo XXI, Definiciones Y Características. Rev. Seres Saberes 2019, 6, 21-24. 
9. Lorenzo Delgado, M.; Hinojo Lucena, F.J.; Aznar Díaz, I.; López Sánchez, M.; Cáceres Reche, M.P.; El Homrani, M. Estudio del Liderazgo estudiantil en el Instituto de Ciências Educativas de Odivelas (ISCE) y la Escola Superior de Educaçao de Portalegre. Rev. Investig. Interv. Soc. ISCE 2007, 2, 11-45.

10. Hermosilla, D.; Amutio, C.; da Costa, S.; Páez, D. El Liderazgo transformacional en las organizaciones: Variables mediadoras y consecuencias a largo plazo. Rev. Psicol. Trab. Organ. 2016, 32, 135-143. [CrossRef]

11. López Gómez, M. El liderazgo Estudiantil en la Universidad Santo Tomás de Bucaramanga: Propuesta Pedagógica. Ph.D. Thesis, Universidad de Granada, Granada, Spain, 2017. Available online: http:/ / hdl.handle.net/10481/45902 (accessed on 24 October 2021).

12. Tintoré, M.; Cantón Mayo, I.; Quiroga Lobos, M.; Parés, I. Liderazgo y e-liderazgo en las historias de vida de líderes educativos a través del mundo. EDMETIC Rev. Educ. Med. TIC 2019, 8, 17-36. [CrossRef]

13. Tolentino, H. Habilidades sociales y estrategias didácticas para la formación del liderazgo desde la educación básica. Rev. Educ. 2020, 4, 690-705. [CrossRef]

14. Pedraja Rejas, L.M.; Marchioni Choque, Í.A.; Espinoza Marchant, C.J.; Muñoz Fritis, C.P. Liderazgo y cultura organizacional como factores de influencia en la calidad universitaria: Un análisis conceptual. Form. Univ. 2020, 13, 3-14. [CrossRef]

15. Bollen, K.A. Structural Equations with Latent Variables; John Wiley \& Sons: New York, NY, USA, 1989; pp. 1-513. [CrossRef]

16. Byrne, B.M. Structural Equation Modeling With AMOS: Basic Concepts, Applications, and Programming, Second Edition Multivariate Applications Series, 2nd ed.; Routledge: New York, NY, USA, 2013; pp. 1-391. [CrossRef]

17. López, J.; Pozo, S.; Fuentes, A.; Romero, J.M. Análisis del Liderazgo Electrónico y la Competencia Digital del Profesorado de Cooperativas Educativas de Andalucía (España). Multidiscip. J. Educ. Res. 2019, 9, 194-223. [CrossRef]

18. Ely, R.J.; Ibarra, H.; Kolb, D.M. Taking gender into account: Theory and design for women's leadership development programs. Acad. Manag. Learn. Educ. 2011, 10, 474-493. [CrossRef]

19. Cáceres, M.P.; Trujillo, J.M.; Hinojo, F.J.; Aznar, I.; García-Carmona, M. Tendencias actuales de género y el liderazgo de la dirección en los diferentes niveles educativos. Educar 2012, 48, 69-89.

20. Sola, T.; Cáceres, M.P.; Trujillo, J.M. Género y poder en el contexto universitario: ¿hacia un liderazgo femenino? In Organizar y Dirigir en la Complejidad: Instituciones Educativas en Evolución, 1st ed.; Manzanares, M., Ed.; Wolters Kluwer: Madrid, Spain, 2010; Volume 1, p. 29.

21. Pareja Fernández de la Reguera, J.A.; López Núñez, J.A.; El Homrani, M.; Lorenzo Martín, R. El liderazgo en los estudiantes universitarios: Una fructífera línea de investigación. Educar 2012, 48, 91-119. [CrossRef]

22. Merma Molina, G.; Ávalos Ramos, M.A. El liderazgo estudiantil y el género: Causas de su elección y problemáticas en su desempeño. Rev. Cienc. Soc. 2018, 1, 143-156.

23. Del Pino Peña, R.; Aguilar Fernández, M.D.L.A. La inteligencia emocional como una herramienta de la gestión educativa para el liderazgo estudiantil. Cuad. Adm. 2013, 29, 132-141. [CrossRef]

24. Santamaría, C.; Sánchez, M.O. Participación y liderazgo estudiantil: Una apuesta por la ciudadanía activa. Colomb. Med. 2013, 42, 103-112. [CrossRef]

25. Marcketti, S.B.; Arendt, S.W.; Shelley, M.C. Leadership in action: Student leadership development in an event management course. Leadersh. Organ. Dev. J. 2011, 32, 170-189. [CrossRef] 